\title{
Use of a gel biopolymer for the treatment of eviscerated eyes: experimental model in rabbits
}

\author{
Uso de um biopolímero na forma gel para o tratamento de olhos eviscerados: modelo experimental em coelhos
}

Francisco de Assis Cordeiro-Barbosa ${ }^{1}$, José Lamartine de Andrade Aguiar², Mariana Montenegro de Melo Lira², Nicodemos Teles de Pontes Filho², SidCley Bernardino-Araújo 3

\begin{abstract}
Purpose:To evaluate histologically the integration process of cellulose gel produced by Zoogloea sp when implanted into rabbits' eviscerated eyes.

Methods: This experimental study employed 36 eyes of 18 rabbits subjected to evisceration of their right eyes. The sclerocorneal bag was sutured and filled with biopolymer from sugar cane in the gel state. All animals were clinically examined by biomicroscopy until the day of their sacrifice which occurred on the $7^{\text {th }}$ $30^{\text {th }}, 60^{\text {th }}, 90^{\text {th }}, 120^{\text {th }}$, or $240^{\text {th }}$ day. The eyeballs obtained, including the left eyes considered controls were sent for histopathological study by optical macroscopy and microscopy. Tissue staining techniques used included hematoxylin-eosin, Masson trichrome (with aniline), Gomori trichrome, Van Gienson, Picrosirius red, and periodic acid-Schiff (PAS).

Results: No clinical signs of infection, allergy, toxicity, or extrusion were observed throughout the experiment. The corneas were relatively preserved. Macroscopic examination revealed a decrease of $\sim 8 \%$ in the volume of the bulbs implanted with the biopolymer. After cutting, the sclerocorneal bag was solid, compact, elastic, and resistant to traction, with a smooth and whitish surface, and showed no signs of necrosis or liquefaction. The episcleral tissues were somewhat hypertrophied. The histological preparations studied in different colors revealed an initial lymphoplasmacytic infiltration, replaced by a fibroblastic response and proliferation of histiocytes, along with formation of giant cells. Few polymorphonuclearneutrophils and eosinophils were also found. Neovascularization and collagen deposition were present in all animals starting from day 30 ; although on the $240^{\text {th }}$ day of the experiment the chronic inflammatory response, neovascularization and collagen deposition had not yet reached the center of the implant.

Conclusion: In this model, the cellulose gel produced by Zoogloea sp proved to be biocompatible and integrated into the orbits. Morphometric, immunohistochemical and biodegradability studies should be performed in the future.
\end{abstract}

Keywords: Eye enucleation; Eye evisceration; Bioprosthesis; Eye, artificial; Saccharum; Orbital implants; Biopolymers; Models, animal; Rabbits

\section{RESUMO}

Objetivos: Avaliar histologicamente o processo de integração do gel da celulose produzida pela Zoogloe asp implantado em olhos eviscerados de coelhos.

Métodos: Estudo experimental utilizando 36 olhos de 18 coelhos. Todoseles tiveram seus olhos direitos eviscerados. A bolsa escleral foi suturada e preenchida com biopolimero da cana de açúcar, no estado gel. Todos os animais foram examinados clinicamente, sob biomicroscopia, até o dia de seus sacrifícios e enucleações que aconteceram no $70,30^{\circ}, 60^{\circ}, 90^{\circ}, 120^{\circ}$ e $240^{\circ}$ dia. Os bulbos obtidos, inclusive os esquerdos, considerados controles, foram encaminhados para estudo histopatológicos de macroscopia e microscopia óptica. As colorações pela hematoxilina-eosina, tricômio de Masson (com anilina), tricômio de Gomori, Van Gienson e Picrosirius red e ácido periódico de Schiff (PAS) foram usadas.

Resultados: Duranteo experimento não foram observados sinais clínicos de infecção, alergias, intoxicação ou extrusão. As córneas apresentavam-se relativamente preservadas. Exame macroscópico revelou uma diminuição de aproximadamente $8 \%$ no volume dos bulbos nos quais o biopolímero foi implantado. O corte do saco escleral mostrou um conteúdo sólido, compacto, elástico, resistente à tração, com superfície lisa e brancacenta. Não foram observados sinais de necrose, ou liquefação. O tecido epiescleral estava algo hipertrofiado. As preparações histológicas estudadas, nas diversas colorações, revelaram uma infiltração linfomonomorfonuclear inicial, substituída posteriormente por uma resposta fibroblástica e proliferação de histiócitos com formação de células multinucleadas gigantes. Foram também encontrados poucos polimorfonucleares neutrófilos e eosinófilos. A partir do 300 dia houve proliferação vascular e deposição de calágeno em todos os espécimes estudados, embora, no $240^{\circ}$ dia do experimento, a resposta inflamatória crônica, a neovascularização e a deposição do colágeno não tinham ainda atingido o centro do implante.

Conclusão: Neste modelo, o gel da celulose produzido pela Zoogloea sp, mostrou-se biocompatível e integrado às órbitas. Estudos morfométrico, imuno-histoquímico e de biodegradabilidade devem ser realizados futuramente.

Descritores: Enucleação ocular; Evisceração do olho; Bioprótese; Olho artificial; Saccharum; Implantes orbitários; Biopolímeros; Modelos animais; Coelhos
Submitted for publication: February 14, 2012

Accepted for publication: May 15, 2012

Study carried out at Department of Surgery and Laboratory of Immunopahology KeizoAssami, Universidade Federal de Pernambuco - UFPE - Recife (PE), Brazil.

${ }^{1}$ Physician, Department of Surgery and Laboratory of Immunopathology KeizoAssami, Universidade Federal de Pernambuco - UFPE - Recife (PE), Brazil.

2 Physician, Department of Pathology and Laboratory of Immunopathology KeizoAssami, Universidade Federal de Pernambuco - UFPE - Recife (PE),Brazil.

Federal de Pernambuco - UFPE - Recife (PE),Brazil.
3 Biologist, Department of Pathology and Laboratory of Immunopathology KeizoAssami,Universidade

Federal de Pernambuco - UFPE - Recife (PE),Brazil.
Funding: This study was supported by Universidade Federal de Pernambuco - UFPE.

Disclosure of potential conflicts of interest: F.A.Cordeiro-Barbosa, Provision of writing assistance, medicines, equipment, or administrative support by Universidade Federal de Pernambuco and Board Membership of University Hospital of Universidade Federal de Pernambuco; J.L.A.Aguiar, Provision of writing assistance, medicines, equipment, or administrative support by Universidade Federal de Pernambuco and Board Membership of University Hospital of Universidade Federal de Pernambuco; M.M.M.Lira, Provision of writing assistance, medicines, equipment, or administrative support by Universidade Federal de Pernambuco and Board Membership of University Hospital of Universidade Federal de Pernambuco; N.T.PontesFilho, Provision of writing assistance, medicines, equipment, or administrative supportby Universidade Federalde Pernambuco and Board Membership equipment, Perion of writing assistance, medicines, equipment, or administrative support by Universidade Federal de Pernambuco and Board Membership of University Hospital of Universidade Federal de Pernambuco. Correspondence address: Francisco Cordeiro-Barbosa. Av. Boa Viagem, 5450/3001 - Recife - PE51030-000 - Brazil - E-mail: oftalpe@hotmail.com

The present study was approved by the Ethics Committee in Animal Experimentation of UFPE following the principles proposed by Association for Research in Vision and Ophthalmology (ARVO). 


\section{INTRODUCTION}

The surgeries of evisceration and enucleation, and an ophthalmic cavity reparative treatment remain challenging and traumatizing procedures from the psychological point of view, both for the patient and for the ophthalmologist. Today, worldwide, the number of patients who have been formally indicated for these types of surgeries continues to be high ${ }^{(1,2)}$. Besides the feeling of loss of the eyeball, the evisceration or enucleation predisposes the individual to esthetic defects such as enophthalmos, deepening of the eyelid superior sulcus, ptosis, incomplete transference of movement to the prosthesis, reduction of the lower fornix, and flaccidity of the lower eyelid(3).

In an attempt to reduce these disappointing results, biotechnology has provided the ophthalmology with a vast array of implants and prostheses, increasingly enhanced for functional plasticity, biocompatibility, and body integration ${ }^{(4,5)}$.

There are numerous types of implants used for replacement of the orbital content of anophthalmic cavities; however, these implants can be distributed into 2 main groups. These groups consist of the inert, non-integrable implants, such as glass and polymethylmethacrylate, and the integrated implants, which have been used since the 1980s, and include spheres of hydroxyapatite, porous polyethylene, and aluminum oxide $\mathrm{e}^{(6-9)}$.

Besides the esthetic problems, any existing orbital implant, integrated or not, subjects the patient to conjunctival dehiscence, infection, and extrusion. There are several causes for these complications. One of them could be the fact that the implants move together with the orbital content, and the external prostheses could cause repeated traumas on the conjunctival surface; therefore, there construction of the anophthalmic cavity with an integrated polymer with a soft and smooth surface could help decrease the frequency of orbital implant extrusion ${ }^{(4,10-12)}$.

In the medical pharmaceutical industry, cellulose is being tested as a replacement for blood vessels, as an envelope for peripheral nerves, a framework of cartilaginous tissues, a substratum for cell culture, a biological dressing for burns, and for use in the fabrication of numerous prostheses, including dressings in veterinary ophthalmology ${ }^{(13-19)}$.

A polymer of cellulose, obtained by bacterial synthesis from sugar cane molasses, has been studied in the Industrial Microbiology Laboratory at Carpina Experimental Station of Sugarcane / Rural University of Pernambuco, since 1990. It is an exopolysaccharide produced from the bacteria Zooglea sp, isolated in the Department of Antibiotics, Federal University of Pernambuco (UFPE). This polymer is being used for the development of prostheses with applications in different subareas of surgery ${ }^{(20)}$.

In its pure state, the polymer has low toxicity, high biocompatibility, elasticity, tensile strength, flexibility, and it can still be modeled in different ways, including as a gel, thus fulfilling the necessary requirements for the manufacture of biological implants (21,22). $^{2}$

The biopolymercellulose gel obtained by bacterial fermentation of Zooglea sp was successfully used in the experimental correction of vesicoureteral reflux in dogs; however, the types of cellular reactions that characterize the integration of the implant were not studied in detail ${ }^{(23)}$. An orbital implant consisting of polyethylene porous gel was tested unsuccessfully by Ferrazand et al. ${ }^{(24)}$. The polyethylene gel showed enormous swelling when in contact with the orbital tissues.

Histopathological studies in cases where porous polyethylene and hydroxyapatite were used as the integrated ophthalmic implants initially reveal a chronic inflammatory reaction in the boundary line between the implant and the host tissue. Histiocytic, fibroblastic and neovessels proliferation occurred along with the formation of multinucleated cells of the foreign body type. Finally, the deposition of collagen fibers indicates repair and integration of the implant into the host ${ }^{(25-27)}$

In this study, an experimental model using rabbits is proposed to evaluate histologically the integration process of an artificial implant of cellulose gel, produced by Zoogloea sp, used to restore eviscerated eyes.

\section{METHODS}

This study employed 36 eyes of 18 healthy, young, California crossbred rabbits. The animals were randomly divided into 6 groups of 3 animals per group. During the experiment, all animals were subjected to evisceration of their right eye, according to a surgical technique recommended in ophthalmic surgery; however, the cornea was preserved. The left eyes were not manipulated and served as clinical and anatomic pathologic controls.

The sclerocorneal bag was sutured with Vicryl ${ }^{\circledR} 6.0$, and the Tenon's capsule and conjunctiva were sutured interruptedly over the sclera in continuous points with the same material; however, a 7.0 diameter Vicryl was used. To facilitate postoperative examinations, the cornea did not suffer conjunctival coating. After closing, the sclerocorneal cavity was filled with $\sim 4.0 \mathrm{~mL}$ of sugar cane bio-polymer gel, previously sterilized by gamma irradiation. In these operated eyes, a combination of ciprofloxacin and dexamethasone in the form of an ointment (Cilodex ${ }^{\circledR}$ ) was used once a day during the first 7 days of the experiment. The animals were sacrificed according to the following preset timetable: GROUP 7 on day 7; GROUP 30 on day 30; GROUP 60 on day 60; GROUP 90 on day 90; GROUP 120 on day 120; GROUP 240 on day 240.

All medical and surgical procedures were performed according to a protocol previously approved by the animal experimentation ethics committee of UFPE.

\section{CLINICAL STUDIES}

All animals were subjected to biomicroscopic examination of the anterior segment of both eyes with a slit lamp. This examination was initially conducted every 24 hours, and after the $7^{\text {th }}$ day, weekly, until the day of sacrifice. These tests were primarily conducted to observe the following signs:

- In the conjunctiva: edema, hyperemia, chemosis, surgical wound dehiscence, extrusion, aqueous, mucous, serous, and bloody purulent secretions, and cellular hypertrophy (papillary, follicles, and granulomas).

- In the cornea: epithelial abrasions, ulcers, "melting," perforation, parenchymal turbidity, endothelial turbidity, keratic precipitates, pannus, and leukoma.

\section{ANATOMOPATHOLOGICAL STUDIES}

After sacrifice, all animals had both eyes enucleated and the eyes were immediately placed in a solution of 10\% buffered formalin for a period of 48 hours. After complete fixation, a macroscopic examination was performed and conducted in 2 stages.

The first stage involved measuring the diameters (sizes) of the bulbs, right and left, by a digital precision caliper, as well as the external description of the bulbs, together with the periocular tissues, using an Olympus stereotactic magnifying glass with a magnification of $\times 10$.

In the second stage, the bulbs were cut up in a sagittal plane in their largest diameters forming 2 approximately equal caps, always in pairs, right and left, with a total of 4 caps for each animal. To provide continuity to the examination with a magnifying glass, we assessed the following parameters: shape, color, texture, presence or absence of implant extrusions, exudates, and physical consistency.

At the end of the macroscopic exam, the caps were washed in distilled water, placed in $70 \%$ ethanol, and then processed by classical histological techniques with paraffin embedding. The microtomy was done in semi-serial cuts of 5 micrometers and tissues were stained for analysis and photographic documentation under light 
microscopy with white light. In the case of Sirius red staining, examination was also done using polarized light. The following staining procedures were used: hematoxylin-eosin, Masson's trichrome (with aniline blue), Gomory's trichrome, Van Gienson, Picrosirius red, and periodic acid-Schiff (PAS).

The qualitative histological analysis, using an Olympus BX53 optical microscope with a DP71 digital camera and a x40 objective lens, was conducted to examine for mononuclear infiltrates (lymphocytes and plasmocytes), polymorphonuclear neutrophils and eosinophils, multinucleated giant cells, neovessels, septum vascular fibroblasts, and deposition of collagen fibers in the intimacy of the implant. Corneas were examined for edema, cellular infiltration, persistence of the endothelium, and neovascularization or pannus. Examinations were also conducted for histological signs of necrosis, calcification, hemorrhage, bacterial remains, suture remains, implant extrusion, and persistence of the natural implant without cellularity or vascularity. The presence of multinucleated giant cells and neovessels although qualitative variables were ordered according to the number of events per microscopic field.

The presence or absence of these variables was recorded on a spread sheet specifically constructed for this purpose.

\section{RESULTS}

The clinical exams performed in eviscerated eyes and recomposed with biopolymers showed mild or moderate conjunctival hyperemia with serobloody secretion in the early days of the experiment, which completely disappeared on day 7. No clinical signs of infection, allergy, toxicity, or extrusion were observed throughout the experiment (Figure 1C). The cornea in all animals remained relatively clear during the first 90 days of the experiment. Slit lamp examination revealed no evidence of keratic precipitates, corneal perforation, or extrusion of the implant above the conjunctiva in any of the animals. The left eyes, considered controls, revealed no changes during the experiment (Figure $1 \mathrm{~A}$ ).

Macroscopic examinations of the left eyeballs (controls), performed after 48 hours of fixation in formalin, revealed an average axial diameter of $17.16 \mathrm{~mm}$ measured at the largest diameter, i.e., from the corneal apex to the posterior sclera in the insertion of the optic nerve. The corneas and the other ocular tissues did not present abnormalities. The right bulbs, those eviscerated and filled with polymergel, presented with a reduction in their anteroposterior diameters, measuring an average of $16.10 \mathrm{~mm}$. The corneas were relatively clear, and the sclera had coloration and consistency characteristics. The episcleral tissues were slightly hypertrophied and brownish color. When cutting, the contents of the sclerocorneal bag were compact, whitish, solid, and somewhat elastic to the touch by the ends of the caliper. No signs of content liquefaction were observed (Figure 1.B). In some bulbs, small darker and discontinued lines were observed between the sclera and the biopolymers.

\section{Microscopic examinations}

The qualitative histological examination (Figure 2) revealed mononuclear infiltrates (Lymphocytes and plasmocytes) (Figure 3C) only in animals sacrificed starting on Day 30. The polymorphonuclear infiltrate (neutrophils and eosinophils) was present from the beginning of the experiment, but it appeared to be low or even absent in some animals after day 60. Multinucleated giant cells (Figure 3D), fibroblasts, and deposition of collagen fibers were present in all animals starting from day 30 (Figure 3B). The vessels in the intimacy of the implant (Figure 3C), and the findings of corneal edema and cellular infiltration had already appeared in the animals sacrificed on day 7. Calcification was present in 8 animals, while necrosis was present only in animal 60.1. Signs suggestive of bacterial remains were present only in animal 7.1. The blades used on various animals showed remains of sutures and small extrusions of $g$ el. On the $240^{\text {th }}$ day of the experiment, the chronic inflammatory response, the neovascularization, and the collagen deposition had not yet reached the center of the implant. The corneal endothelial cell monolayer (Figure 3A) was barely visible in the animals 240.1 and 240.2.

\section{DISCUSSION}

On clinical examination (Figure $1 \mathrm{C}$ ), the absence of intense edema, conjunctival hyperemia, papillary or follicular proliferation, secretions (mucopurulent and bloodymucus), perforation, or early corneal opacification in the eyes that received the polymer suggests that there was no clinically acute disease with the participation of bacteria of high virulence, as occurs in extrusion of solid implants ${ }^{(27)}$. There were also no signs of acute process, allergic or toxic, which would have suggested a lack of biocompatibility. The results from cytotoxicity testing ${ }^{(21)}$ support these findings, because they showed the sugarcane biopolymer to have a biocompatibility similar to those of expanded polytetrafluoroethylene (PTFE) and polypropylene (Prolene ${ }^{\circledR}$ ), which are widely used in general and ophthalmologic surgeries.

The macroscopic study demonstrated that the implant decreased by $\sim 8 \%$ of its original volume. Because the polymer gel in its natural state is rich in water ${ }^{(20)}$, and the scleral and periocular tissues have a higher line concentration, it was expected to find a decrease in the volume of the implant due to the escape of solvent, following the concentration gradient. In humans, this reduction would be acceptable because it would correspond to the additional volume of the prosthesis (Figure 1D). On the other hand, we know from tissue engineering studies that cellulose produced by bacteria can be mixed with various substances and there by alter their rates of dehydration, biocompatibility, biodegradability, or biomechanical characteristics. Therefore, we can exert control over the final volume of a gel implant.
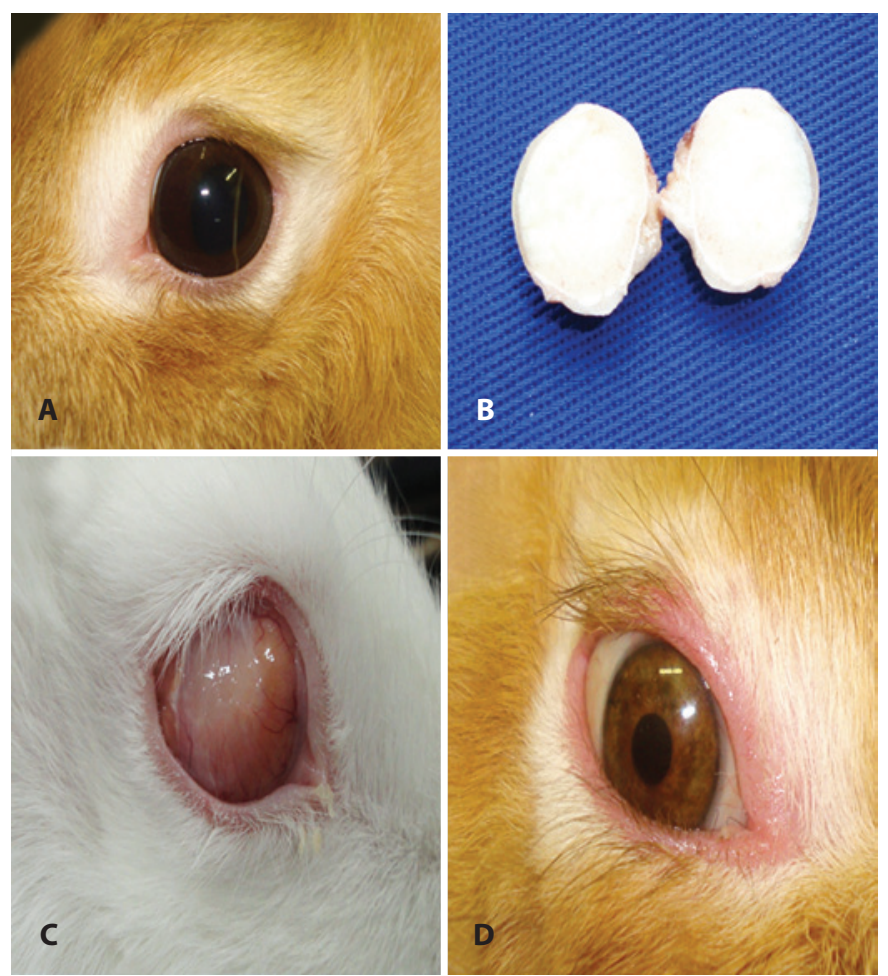

Figure 1. A) Left eye (control). B) Macroscopic appearance of the implanted eyeball showing compact substance, whitish, solid, and surrounded by an elastic sclera with normal color and consistency. C) Orbital aspect of an albino animal that received the implant Gel 210 days earlier. Note that vessels within the implant through the cornea are still partially transparent. D) Final appearance of a human prosthesis on the implant, animal on day 210 of the experiment. 


\begin{tabular}{|c|c|c|c|c|c|c|c|c|c|}
\hline $\begin{array}{c}\text { ANIMAL } \\
\text { GROUPS }\end{array}$ & -YMPH / PLASM & NEUTROPHIL & EOSINOPHILS & $\begin{array}{c}\text { GIANTS } \\
\text { CELL/FIELD }\end{array}$ & \begin{tabular}{|c} 
VASCULAR \\
SEPTO
\end{tabular} & VESSELS/FIELD & FIBROBLASTS & FIBROSIS & $\begin{array}{l}\text { CORNEAL } \\
\text { EDEMA }\end{array}$ \\
\hline 7.1 & ABSENT & PRESENT & PRESENT & 0,00 & PRESENT & 5.8 & ABSENT & ABSENT & PRESENT \\
\hline 7.2 & ABSENT & PRESENT & PRESENT & 0,00 & ABSENT & 0 & ABSENT & ABSENT & PRESENT \\
\hline 7.3 & ABSENT & PRESENT & PRESENT & 0,00 & PRESENT & 9.8 & ABSENT & ABSENT & PRESENT \\
\hline 30.1 & PRESENT & PRESENT & PRESENT & 1,10 & ABSENT & 3.5 & PRESENT & PRESENT & PRESENT \\
\hline 30.2 & PRESENT & PRESENT & PRESENT & 1,30 & ABSENT & 4.2 & PRESENT & PRESENT & PRESENT \\
\hline 30.3 & PRESENT & PRESENT & PRESENT & 1,30 & ABSENT & 4.2 & PRESENT & PRESENT & PRESENT \\
\hline 60.1 & PRESENT & PRESENT & PRESENT & 9,80 & ABSENT & 4.1 & PRESENT & PRESENT & PRESENT \\
\hline 60.2 & PRESENT & PRESENT & PRESENT & 7,30 & ABSENT & 4.6 & PRESENT & PRESENT & PRESENT \\
\hline 60.3 & PRESENT & ABSENT & PRESENT & 1,90 & ABSENT & 5.0 & PRESENT & PRESENT & PRESENT \\
\hline 90.1 & PRESENT & ABSENT & PRESENT & 10,70 & PRESENT & 3.7 & PRESENT & PRESENT & ABSENT \\
\hline 90.2 & PRESENT & ABSENT & PRESENT & 8,20 & ABSENT & 2.0 & PRESENT & PRESENT & ABSENT \\
\hline 90.3 & PRESENT & ABSENT & PRESENT & 12,10 & ABSENT & 3.0 & PRESENT & PRESENT & ABSENT \\
\hline 120.1 & PRESENT & PRESENT & PRESENT & 6,30 & PRESENT & 5.1 & PRESENT & PRESENT & ABSENT \\
\hline 120.2 & PRESENT & ABSENT & PRESENT & 7,20 & ABSENT & 2.8 & PRESENT & PRESENT & ABSENT \\
\hline 120.3 & PRESENT & ABSENT & PRESENT & 10,70 & ABSENT & 3.9 & PRESENT & PRESENT & PRESENT \\
\hline 240.1 & PRESENT & PRESENT & PRESENT & 11,50 & PRESENT & 3.0 & PRESENT & PRESENT & ABSENT \\
\hline 240.2 & PRESENT & PRESENT & ABSENT & 23,80 & PRESENT & 3.1 & PRESENT & PRESENT & ABSENT \\
\hline 240.3 & PRESENT & ABSENT & ABSENT & 23,80 & PRESENT & 9.8 & PRESENT & PRESENT & PRESENT \\
\hline $\begin{array}{l}\text { ANIMAL } \\
\text { GROUPS }\end{array}$ & $\begin{array}{l}\text { CORNEAL } \\
\text { INFILTRATES }\end{array}$ & $\begin{array}{c}\text { CORNEAL } \\
\text { NEOVESSEL }\end{array}$ & CALCIFICATIO & NECROSIS & $\begin{array}{l}\text { BACTERIAL } \\
\text { REMAINS }\end{array}$ & $\begin{array}{l}\text { SUTURE } \\
\text { REMAINS }\end{array}$ & $\begin{array}{c}\text { MICRO } \\
\text { EXTRUSION }\end{array}$ & $\begin{array}{c}\text { POLIMER } \\
\text { WITHOUT } \\
\text { NEOVESSELS }\end{array}$ & $\begin{array}{l}\text { CORNEAL } \\
\text { ENDOTHELIUM }\end{array}$ \\
\hline 7.1 & PRESENT & ABSENT & ABSENT & ABSENT & PRESENT & PRESENT & ABSENT & PRESENT & ABSENT \\
\hline 7.2 & PRESENT & ABSENT & ABSENT & ABSENT & ABSENT & ABSENT & ABSENT & PRESENT & ABSENT \\
\hline 7.3 & PRESENT & ABSENT & ABSENT & ABSENT & ABSENT & ABSENT & PRESENT & PRESENT & ABSENT \\
\hline 30.1 & PRESENT & PRESENT & ABSENT & ABSENT & ABSENT & ABSENT & ABSENT & PRESENT & ABSENT \\
\hline 30.2 & PRESENT & PRESENT & ABSENT & ABSENT & ABSENT & ABSENT & PRESENT & PRESENT & ABSENT \\
\hline 30.3 & PRESENT & PRESENT & ABSENT & ABSENT & ABSENT & ABSENT & PRESENT & PRESENT & ABSENT \\
\hline 60.1 & PRESENT & PRESENT & PRESENT & PRESENT & ABSENT & PRESENT & PRESENT & PRESENT & ABSENT \\
\hline 60.2 & PRESENT & PRESENT & ABSENT & ABSENT & ABSENT & ABSENT & PRESENT & PRESENT & ABSENT \\
\hline 60.3 & PRESENT & PRESENT & PRESENT & ABSENT & ABSENT & PRESENT & PRESENT & PRESENT & ABSENT \\
\hline 90.1 & AUSENT & PRESENT & PRESENT & ABSENT & ABSENT & ABSENT & ABSENT & PRESENT & ABSENT \\
\hline 90.2 & PRESENT & PRESENT & PRESENT & ABSENT & ABSENT & AUSENTE & ABSENT & PRESENT & ABSENT \\
\hline 90.3 & ABSENT & PRESENT & PRESENT & ABSENT & ABSENT & PRESENT & ABSENT & PRESENT & ABSENT \\
\hline 120.1 & ABSENT & PRESENT & PRESENT & ABSENT & ABSENT & PRESENT & PRESENT & PRESENT & ABSENT \\
\hline 120.2 & ABSENT & PRESENT & ABSENT & ABSENT & ABSENT & ABSENT & PRESENT & PRESENT & ABSENT \\
\hline 120.3 & ABSENT & PRESENT & PRESENT & ABSENT & ABSENT & ABSENT & PRESENT & PRESENT & ABSENT \\
\hline 240.1 & ABSENT & PRESENT & PRESENT & ABSENT & ABSENT & PRESENT & PRESENT & PRESENT & PRESENT \\
\hline 240.2 & ABSENT & PRESENT & ABSENT & ABSENT & ABSENT & ABSENT & ABSENT & PRESENT & PRESENT \\
\hline 240.3 & PRESENT & PRESENT & ABSENT & ABSENT & ABSENT & ABSENT & ABSENT & PRESENT & ABSENT \\
\hline
\end{tabular}

Figure 2. The histological study was conducted to identify cells involved in the phenomena of infections, allergies or inflammation (acute or chronic). Neovascularization, necrosis, calcification, and fibrosis were also studied.
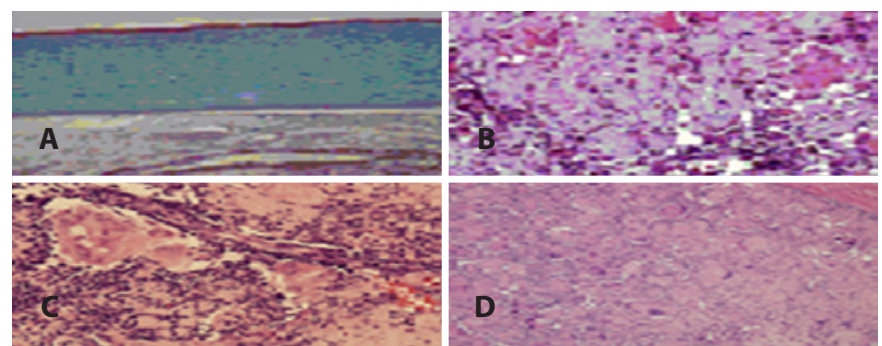

Figure 3. A) Masson trichrome (x100). Biopolymer-cornea Interface: corneal epithelium, membrane of Bowman, stroma, and Descemet, relatively preserved. In some points,we see remains of the endothelial monolayer. Deposit of collagen fibers and neovascularization of the implant surface. B) Masson trichrome- $x 200$ : Interior of the implanted gel: lymphocytic infiltration, multinucleated giant cells, neovessels, and collagen deposition represented by tones of blue aniline. C) Hematoxylin-eosin (HEx200). Interior of the implanted substance: infiltrated lymphoplasmacyte that passes through the scleral tissue and reaches the interior. Histiocytes arranged in multinucleated giant cells forming a granuloma. Presence of vacuoles with biopolymerinthe cytoplasm of these cells. Also observe indicative points of neovascularization. D) Hematoxylin-eosin (HEx100). Sclera-polymer interface: Tissue showing congestion and edema. Scleras showing their characteristic longitudinal fibers. Presence of numerous multinucleated cells.

The non-liquefaction of the sclerocorneal bag and its implant in all animals supports the argument that there was no infection or collagenolytic activity of the sclera, cornea or its contents after cell invasion (Figure 1B). However, the hypertrophy of the episcleral tissue indicates that the inflammation induced by the implant was beyond the limits of its continent, and reached other tissues. This is similar to what can happen in histopathological experimental studies using other organs ${ }^{(19)}$. In particular, the histological findings in the present study, showing micro-extrusions in most of the slides investigated, initially suggested that the suture of the sclerocorneal bag should be as accurate as possible. In reality, these microleaks may explain the hypertrophies of the episcleral tissues seen in macroscopic exams. These findings did not affect the exam with the slit lamp because the gel leak was always contained by the covering of the Tenon's capsule.

Histological findings supported the clinical exams because the implanted biopolymer was nontoxic and biocompatible ${ }^{(28)}$. There was focal necrosis in only one animal, and it was related to remnants of suture material. There were hemorrhages in histological specimens, only in animals 7.2 and 7.3, and they were probably related to surgery. In some animals, there was the presence of calcification, but there was no relation with areas of necrosis, which excludes the chances of a dystrophic calcification.

Despite the rigorous evisceration, in some animals, there were small amounts of crystalline material and uveal tissue. Studies on the pathology of uveitis have shown that the uveal tissues (iris, ciliary body, and choroid), and the crystalline material, when traumatized, trigger an inflammatory response initially mediated by monomorphonuclear lymphocytes and plasma cells. This response is usually followed by a histiocytic response with the possibility of formation of multinucleated giant cells-foreign body type, precisely located with the rest of the material in question (29). It is worth noting, however, that in the present study, the chronic inflammatory reaction occurred indiscriminately at all sites studied in all animals, regardless of the presence or absence of uveal or crystalline residuals. In histopathological studies using lyophilized cellulose in peripheral nerve injuries in dogs, researchers observed the presence of a chronic fibroblastic reaction (multinucleated cells-foreign body type), which was followed by the deposition of collagen ${ }^{(19)}$. 
In the present study, special staining (Van Gienson, Massontrichrome, Gomory, Picrosirius Red, and periodic acid-Schiff (PAS) (Figure $4 \mathrm{~A}, \mathrm{~B}, \mathrm{C}$ e D) verified a chronic inflammatory neovascularization, and fibroblastic response, as well as collagen deposition in all animals starting from day 30. In the same animals, the presence of these fibers appeared to follow the multinucleated giant cells and the neovessels as they entered the implanted material. The collagen does not only form a walling capsule around the implant, but also penetrates the intimacy of the material (Figure 4A). This penetration was well evidenced in those animals that spent a longer time in the experiment. When observing the vascular neogenesis in the preparations from different animals throughout the experiment, we noticed that it had the same characteristics starting at the periphery and moved toward the center; also, it was larger in animals that survived longer prior to sacrifice. Several histological cuts from different animals showed longitudinal cuts of these vessels, demonstrating the formation of vascular septa (Figure 3C). It is noteworthy that even in the last animals sacrificed on day 240 , the center of the implant had not been occupied by the cellular response, neovessels, or collagen fibers. The pathological phenomena described above support the integration of the implant into the host and were similar to the phenomena observed in previous studies, including those reviewed by Sami, involving other materials and implants ${ }^{(4,7,27)}$. When using an integrated polyethylene implant, Ferraz and colleagues observed the formation of a pseudo capsule around this substance and neovessels, together with fibrovascular tissue filling the spaces between the grains of material ${ }^{(26)}$. In white light microscopy, fibers composed of collagen type I were identified by being acidophilus, and colored pink with eosin, green with Gomori trichrome, blue with Masson (with aniline), magenta with van Gienson, and red with Sirius red (Figure 4). Howe-
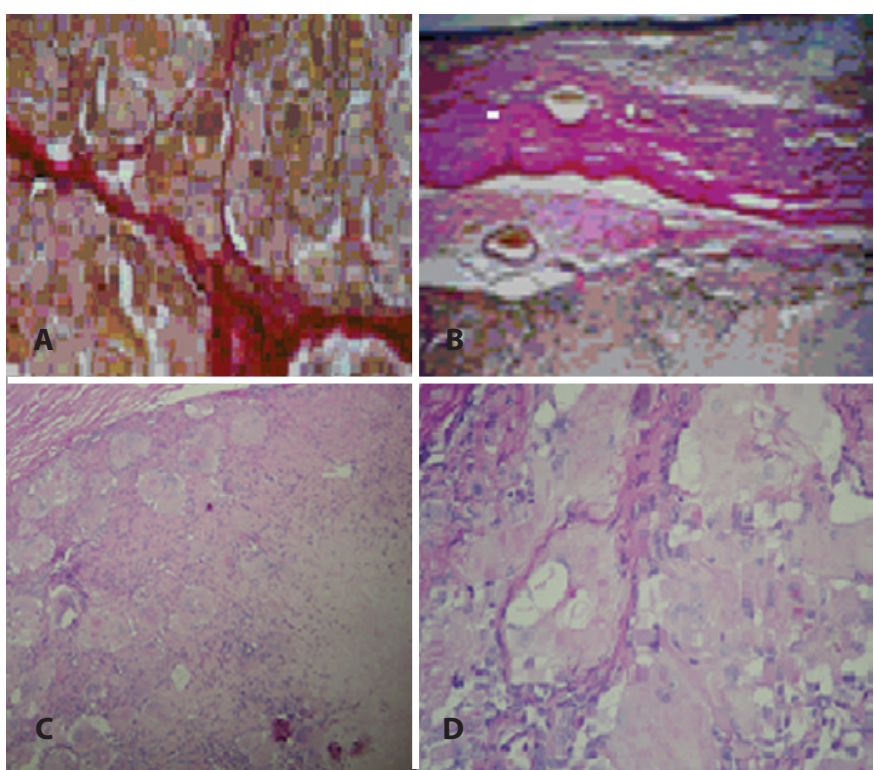

Figure 4. A) Colored with Picrosirius red (x200) under white light showing the intimacy of the implant where the cytoplasm of multinucleated cells display their large vacuoles containing biopolymers. Note neovessels and collagen fibers invading the interior of the implant. B) Van Gienson: x100: Histopathology of the gel on the interface with the cornea, showing corneal edema and deep stromal neovascularization. Deposit of collagen fibers between Descemet membrane and the biopolymer. Neovascularization of the periphery of the gel implant. Cell nuclei are dark, indistinct, and interspersed with the implanted material, as well as the cytoplasm of multinucleated cells. C) Histology aspect of the biopolymer gel implant showing deposition of collagen material between multinucleated giant cells with the sclera. Note greater histiocytic and fibroblastic activity in the periphery and center of the implant: periodic acid-Schiff (PAS) $\times 100$. D) Histopathological aspect of the biopolymer gel implant colored with PAS, to a greater increase (x200), showing in particular the intense magenta coloration, suggesting the presence of collagen material. ver, reticular fibers, formed mainly of collagen type III, are observed as thin black lines after using the PAS method. On the other hand, when the preparations colored with Sirius red are seen by polarized light microscopy, due to birefringence of the collagen fibers, colors of different wave lengths can be identified ranging from red to green, passing through orange and yellow. The more red tones represent the mature collagen (typel) with thicker fibers, while the green tones represent the thin immature collagen or reticular fibers (type III)(30). In agreement with the above descriptions in the literature, in this experiment, polarized light microscopy of preparations colored with Sirius Red showed colored tones against a dark background; especially in those animals sacrificed on or after day 30. These color images, ranging from red to green, passing through yellow and orange, strongly suggest the presence of deposits of collagen fibers. Future immunohistochemical studies will identify all types of collagens deposited during the implantation of a sugar cane biopolymer gel implant. Given the present results, it is clear that the deposition of collagen after a fibroblastic and neovesselgenic response represents an excellent sign of repair and remodeling of extracellular matrix, as well as tissue integration.

\section{CONCLUSION}

In this experimental model, the gel from cellulose produced by Zoogloea sp from sugar cane molasses was shown to be integrated, biocompatible, and nontoxic to the orbits of rabbits.

New experimental studies, especially morphometric, immunohistochemical and biodegradability should be conducted using the same material, not only to consolidate the findings above, but also end or sing its use in other animals, and also in humans.

\section{ACKNOWLEDGMENTS}

Professor Antonio Roberto de Barros Coelho and the Center for Experimental Surgery of UFPE, Recife (PE) - Brazil.

\section{REFERENCES}

1. Amaro TA, Yazigi L, Erwenne C. Aspectos psicológicos e qualidade de vida em pacientes com melanoma uveal durante o processo de tratamento por remoção do bulbo ocular. Arq Bras Oftalmol. 2006;69(6):889-94.

2. Rasmussen ML, Prause JU, Johnson M, Kamper-Jorgensen F, Toft PB. Review of 345 eye amputations carried out in the period 1996-2003, at Rigshospitalet, Denmark. Acta Ophthalmol. 2010;88(2):218-21.

3. Takahagi RU, Goncalves F, Schellini SA, Padovani CR. Avaliação quantitativa das dimensões óculo-palpebrais em portadores de cavidade anoftálmica em uso de prótese ocular externa. Arq Bras Oftalmol. 2005;68(4):517-20.

4. Sami D, Young S, Petersen R. Perspective on orbital enucleation implants. Surv Ophthalmol. 2007;52(3):244-65.

5. Araf D, Assae OM, Brito RV, Aquino Jr G, Silva TA. Miscellaneous orbital implant for anophthalmic cavity reconstruction surgery: case report. Arq Bras Oftalmol. 2010; 73(1):81-3.

6. Perry AC. Integrated orbital implants. Adv Ophthalmic Plast Reconstruct Surg. 1988; 8:75-81.

7. Rubin PA, Popham JK, Bilyk JR, Shore JW. Comparison of fibrovascular ingrowth into hydroxyapatite and porous polyethylene orbital implants. Ophthal Plast Reconstr Surg. 1994;10(2):96-103.

8. Yoon JS, Lew H, Kim SJ, Lee SY. Exposure rate of hydroxyapatite orbital implants: A 15-year experience of 802 cases. Ophthalmology. 2008;115:566-72.e2. Comment in: Ophthalmology. 2008;115(12):2320-1; author reply 2321. Opthalmology. 2008; 115(11):2096; author reply 2096-7.

9. Jordan DR, Gilberg S, Mawn LA. The bioceramic orbital implant: experience with 107 implants. Ophthal Plast Reconstr Surg. 2003;19(2):128-35.

10. Schellini SA, Ichida FK, Padovani CR. Extrusão dos implantes em portadores de cavidade anoftálmica. Arq Bras Oftalmol. 2007;70(5):752-5.

11. Huang D, Yu Y, Lu R, Yang H, Cai J. A modified evisceration technique with scleral quadrisection and porous polyethylene implantation Am J Ophthalmol. 2009;147(5): 924-8.

12. Shoamanesh A, Pang,NK, Oestreicher JH. Complications of orbital implants: a review of 542 patients who have undergone orbital implantation and 275 subsequent peg placements. Orbit. 2007;26(3):173-82. 
13. Yamanaka S, Ono E, Watanabe K, Kusakabe M, Suzuki Y, inventors; Hollow microbial cellulose, process for preparation thereof, and artificial blood vessel formed of said cellulose. European patent, EP0396344A2. 1990 Nov. 07.

14. Klemm D, Udhardt U, Marsch S, Shumann J, inventor. Method and device for producing shaped microbial cellulose for use as a biomaterial, especially for microsurgery. United State patent US2003/0013163, 200316 Jan. Available from: http://www. delphion.com

15. Oster GA, Lentz Y, Koehler K, Hoon R, Serafica G, Mormino R, et al. Solvent dehydrated microbially-derived cellulose for in vivo implantation. United State Patent US6599518, 200329 Jul.

16. Damien C, Heather AB, Oster GA Wright ES, Serafica G, inventor; Xylos Corportion, assignee. Dura substitute and a process for producing the same. United State patent US20050042263A1, 200524 Feb. Available from: http://www.delphion.com.

17. Brik D. Aplicação de película de celulose em lesões epiteliais da córnea. Estudo experimental comparativo. Rev Bras Oftalmol. 1991;50(4):215-20.

18. Schoenau LS, Pippi NL, Schossier JEV. Avaliação clínica preliminar do fechamento comparativo de incisões corneanas com sutura e Biofill (Película Celulósica). Ciênc Rural 1993;23(2):173-7.

19. Mello LR, Feltrin Y, Selbach R, Macedo JG, Spautz C, Haas LJ. Uso da celulose liofilizada em lesões de nervos periféricos com perda de substância. Arq Neuropsiquiatria. 2001;59(2-B):372-9.

20. Beedle MP, Kennedy JF, Melo FAD, Lloyd LL, Medeiros VA. A cellulosic exopolysaccharide produced from sugarcane molasses by a Zooglea sp. Carbohydr Polym. 2000; 42(4):375-83.

21. Castro CM, Aguiar JL, Melo FA, Silva WT, Marques E, Silva DB. Citotoxidade de biopolímero de cana-de-açúcar. Na Fac Med Univ Fed Pernamb. 2004:49(2):119-23.
22. Silveira AA, Dantas ML, Almeida YM, Aguiar JL. Estudo biomecânico de membranas de biopolímero da cana de açúcar perfuradas e continuas implantadas no celular subcutâneo da parede abdominal de ratos. An Fac Med Univ Fed Pernamb. 2007; 52(1):55-9.

23. Rangel $A E$, Aguiar JL, Lima SV, Araújo FC, Vilar FO, Pires JA.A new biomaterial for the treatment of vesicouretral reflux: experimental study. Int Braz J of Urol. 2006;32 (Suppl. 2):A184. Apresentado no: XXVIII Congreso de la Confederación Americana de Urologia-CAU, 2006. Recife, Jun. $17-22$

24. Ferraz LC, Schellini SA, Wludarski SL, Padovani CR. Implantes de polietileno gel e poroso em cavidade anoftálmica de coelhos. Arq Brás Oftalmol. 2006:69(3):304-8.

25. Tambe K, Pushpoth S, Mudhar HS, Sandramouli S. A histopathologic study of orbital implant vascularization. Orbit. 2009;28(1):50-7

26. Ferraz LC, Schellini SA, Wludarski SL, Padovani CR, Müller S. Uso de 2-octil-cianoacrilato na reconstrução da cavidade anoftálmica de coelhos. Arq Bras Oftalmol. 2007; 70(2):221-4.

27. Chuo JY, Dolman PJ, Ng TL, Buffam FV, White VA. Clinical and histopathologic review of 18 explanted porous polyethylene orbital implants. Ophthalmology. 2009; 116(2):349-54.

28. Kim J, Cai Z, Chen Y. Biocompatible bacterial cellulose composites for biomedical application. J Nanotechnol Eng Med. 2010;1(1):1-7.

29. Martins MC, Burnier Jr MN. Anatomia patológica das uveítes. In: Oréfice F, Editor. Uveite: clínica \& cirúrgica:texto \& atlas. 2ª ed. Rio de Janeiro: Cultura Médica; 2005. v.1. p.305-14.

30. Junqueira LC, Bignolas G, Brentani RR. Picrosirius staining plus polarization microscopy, a specific method for collagen detection in tissue sections. Histochem. J. 1979; 11(4):447-55

\section{$38^{\circ}$ Congresso da Sociedade Brasileira de Retina e Vítreo}

\section{1 a 13 de abril de 2013}

Minas Centro

Belo Horizonte (MG)

Informações:

Tel.: (11) 5081-7028

E-mail: retina@fernandapresteseventos.com.br Site: www.retina2013.com.br 